\title{
THE EFFECT OF DISEASES ON FOOD CONSUMPTION AND WEIGHT GAIN IN CAPTIVE COMMON BUZZARDS (Buteo buteo)
}

\author{
OKOLI, C.P. ${ }^{1}$; AIYEDUN, J.O. ${ }^{2}$ and OLUDAIRO, O.O. ${ }^{2}$ \\ ${ }^{1}$ Department of Veterinary Medicine and Surgery, Faculty of Veterinary Medicine, University of Abuja, Nigeria \\ ${ }^{2}$ Department of Veterinary Public Health and Preventive Medicine, Faculty of Veterinary Medicine, University of Ilorin, \\ Nigeria.
}

Received: 16 December 2015; Accepted: 27 January 2016

\begin{abstract}
Disease conditions invariably affect the activities and physiology of common buzzards irrespective of whether they are non-infectious or infectious. The impact of these diseases is further compounded by the stress of captivity in rehabilitation facilities. The aim of the study is to relate weight gain and food consumption to disease conditions in common buzzard. Fifty common buzzards were studied in five batches of 10 birds at a time. The absolute quantity of meat consumed was recorded after taking cognizance of the moisture lost by evaporation. Birds with infectious, non-infectious and those with both non-infectious and infectious diseases on the average consumed $111.9 \mathrm{~g}, 116.6 \mathrm{~g}$ and $110.3 \mathrm{~g}$ of food daily, while their weight gain was $18.8 \%, 12.2 \%$ and $17.6 \%$ respectively. There were only slight differences in the amount of food consumed and percentage weight gained by the 3 categories of birds.
\end{abstract}

Key words: Captive Common Buzzards, Diseases, Food Consumption, Weight Gain.

\section{INTRODUCTION}

Diseases are specific abnormal pathological conditions that affect part or all of an organism which may include a disorder of structure or function culminating in signs and death if not properly treated. Diseases can be infectious, non-infectious, genetic or auto-immune. Diseases are generally known to affect animals in various ways ranging from loss of appetite, loss of weight, reduced libido, infertility, inactivity and evenually death.

Captivity is stressful and some of the factors that could lead to stress include excess cold or heat, starvation overcrowding and restraint (Von Faber, 1964). Stress leads to the release of glucagon, adrenaline and non adrenaline in the circulatory system (Freeman, 1976). None domesticated birds suffer from stress as a result of prolonged period of poor managemnet and disease (Cooper, 1985b). Avoidance of extreme temperature, adequate nutrition and prompt attention to diseases are practical ways of controlling stress in animal population. The infectious diseases which the studied buzzards were diagnosed of included ectoparasitism, capillariasis, trichomoniasis and gas gangrene while the non-infectious conditions include laxation, dehydration, broken feather and, bruised beak.

Corresponding author: OLUDAIRO, O.O.

E-mail address: oludairo@hotmail.com

Present address: Department of Veterinary Public Health and Preventive Medicine, Faculty of Veterinary Medicine, University of Ilorin, Nigeria.
Infestation with feather mites predisposed a free livng eagle to aspergillosis and pseudomonas which ended in fatality (Mumcuoglu et al., 1974). Male parasite toads can influence female mating preference (Houde and Torio, 1992, Hamilton and Zuk, 1982). Bright plumages in birds indicate genetic resistance to parasites (Hamilton and Zuk, 1982). Also Capillaria Contorta of the upper alimentary tract can cause disease of varying severity (Trainer $e t$ al., 1968, Cooper, 1985b).

Prey items can act as intermidiate hosts. Parasitism is quite high in captive birds of prey, but it can be minimised by good hygiene, avoidance of infested or contaminated food items, routine fecal examination, blood screening, regular and prompt treatment of newly admitted and carrier birds (Cerna and Louckeva, 1977).

Only a few birds of prey will take food other than flesh such as the African Harrier Hawk that eats oil palm nuts (Cooper, 1985a, Brown and Amadon, 1988).

Nutritioncan play a number of roles in mediating potential for a disease state in both the genesis and the management of several common diseases. Metabolic diseases problemsmay be associated with either deficient or excessive nutrients intake (Elghandour et al., 2013).

Nutrition is such an important aspect of rehabilitation efforts for captive wild birds as inadequate food 
supply in terms of quantity or quality has deliterious effects. Inanition or exhaustion from lack of nutrient can kill free living birds while under-fed birds have the pectoral muscles wasted through tissue catabolism.

\section{MATERIALS AND METHODS}

After clinical examination, diagnosis and recording, 50 common buzzards were randomly picked for the investigation. The birds were weighed with electronic weighting scales and put individually in perforated paper boxes measuring $90 \mathrm{~cm}$ x $75 \mathrm{~cm} \times$ $75 \mathrm{~cm}$. The paper boxes were all kept in one large room on top of raised wooden pallets. In the rehabilitation facility, common buzzards were fed with pre-slaughtered frozen bony chicken. The chicken was brought ahead of time, chopped into smaller pieces and allowed to thaw slowly. Clean flat round bottom ceramic bowls $2 \mathrm{~cm}$ deep with a diameter of $12 \mathrm{~cm}$ were used in serving the chicken. The ceramic bowls were weighed and recorded. Thereafter a handful of the thawed chicken was put into the bowl and their combined weight recorded to determine the quantity of meat served. The weighed meat was thereafter lowered into the boxes containing individual common buzzards labeled B1B50.

Each bird was kept in one box throughout the study period and the boxes were destroyed at the end of the study as the birds were transferred into bigger rooms. The birds were closely monitored for 24hours till the next morning when the buzzards were carefully picked up wrapped with clean dry cloth, while the leftover meat was gathered and the weight recorded.
The underlay glossy paper was changed and the bird put back in the box.

The leftover meat were gathered and put in the ceramic bowl and weighed. The weight of the ceramic bowl which has been predetermined was subtracted from the combined weight to determine the quantity of the meat left over. After the measurement of the leftover meat for each bird, the birds were returned and another meat for the day weighed and served. The buzzards were studied in batches of 10 for a period ranging from 30 to 36 days each. The quantity of meat consumed by buzzards for each day was determined by subtracting the quantity of leftover meat from the quantity of meat served the bird the previous day. The birds were served once a day and the records were compiled and kept throughout the study period for an overall average daily consumption to be computed. In the course of the study, the weight of the birds were taken at fairly equal intervals about 5 times each and recorded. The average of the five weights $\mathrm{W}_{1}-\mathrm{W}_{5}$ was used as the average weight of the studied common buzzards.

In order to take cognizance of moisture lost by the served meat meals to the atmosphere through evaporation, controls were set up each day of the study. The same quantity of meat served the buzzards each day was put in ceramic bowls of the same capacity and dimension and lowered into the $26^{\text {th }}$ paper box in the same room without any buzzard. The meat in the control bowl was reweighed the next day and recorded. The difference in weight represented the amount of moisture lost to the atmosphere by the meat through evaporation.

\section{RESULTS}

Table 1: Clinical conditions, average quantity of food consumed daily, initial weight, final weight and weight gain of buzzard $(\mathrm{g})$.

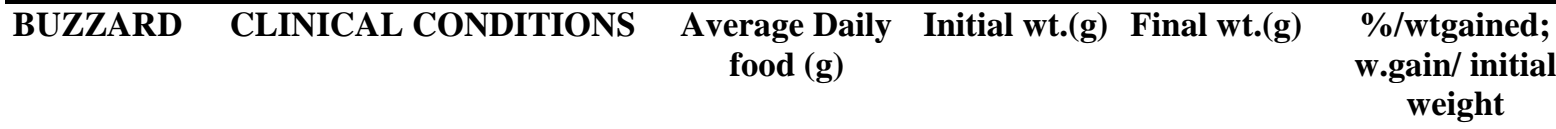

\begin{tabular}{lccccc}
\hline B1 & Ascariasis, Emaciation & 97.9 & 628.4 & 791.7 & 26 \\
\hline B2 & Capillariasis & 96 & 596 & 683 & 14.6 \\
\hline B3 & Emaciation, Fracture & 113.4 & 622 & 822.2 & 32.2 \\
\hline B4 & $\begin{array}{c}\text { Capillariasis, Coccidiosis } \\
\text { Fracture }\end{array}$ & 106.4 & 579 & 698.8 & 20.7 \\
\hline B5 & $\begin{array}{c}\text { Capillariasis, Bruised beak, } \\
\text { weakness }\end{array}$ & 118.4 & 569.3 & 711 & 24.9 \\
\hline B6 & $\begin{array}{c}\text { Capillariasis, Coccidiosis, } \\
\text { wound ankylosis }\end{array}$ & 101.5 & 796 & 950.1 & 19.4 \\
\hline B7 & $\begin{array}{c}\text { Capillariasis, Gastroenteritis, } \\
\text { Luxation }\end{array}$ & 107.8 & 695 & 908.4 & 30.7 \\
\hline
\end{tabular}




\begin{tabular}{|c|c|c|c|c|c|}
\hline B8 & Capillariasis & 120.5 & 623.5 & 855.4 & 37.2 \\
\hline B9 & $\begin{array}{c}\text { Ascariasis, } \\
\text { CapillaraisCoccidiosis, } \\
\text { Dehydration }\end{array}$ & 110.6 & 559 & 733.3 & 31.3 \\
\hline B10 & Emaciation, wound & 125 & 669 & 821.1 & 22.7 \\
\hline B11 & Weakness, nervousness & 130.2 & 551 & 656.8 & 19.2 \\
\hline $\mathrm{B} 12$ & Gastroenteritis & 125.1 & 601.4 & 661.4 & 10 \\
\hline B13 & Occulitis, emaciation & 114.2 & 661.4 & 695.4 & 5.1 \\
\hline B14 & Abdominal tumor & 104.2 & 564 & 579.7 & 2.8 \\
\hline B15 & Weakness & 127.7 & 689 & 831 & 20.6 \\
\hline B16 & Bruised beak, Gastronteritis & 111.7 & 633.9 & 737.2 & 16.3 \\
\hline B17 & Occulitis, Dehydration & 122.3 & 603.5 & 809 & 34.1 \\
\hline B18 & Dehydration & 111.7 & 591.3 & 716 & 21.1 \\
\hline B19 & Fracture & 118.3 & 683.9 & 801.5 & 17.2 \\
\hline B20 & Coccidiosis & 110.1 & 753.5 & 913.2 & 21.2 \\
\hline B21 & $\begin{array}{l}\text { Broken feathers, } \\
\text { Ectoparasitism }\end{array}$ & 113.1 & 629 & 753.5 & 19.8 \\
\hline B22 & Trichomoniasis & 119.9 & 557.4 & 808 & 45 \\
\hline B23 & Ectoparasitism & 127.5 & 499 & 637.1 & 27.7 \\
\hline B24 & Ectoparasitism & 121.6 & 565 & 703 & 24.4 \\
\hline $\mathrm{B} 25$ & Ectoparasitism & 123.3 & 654.2 & 857 & 31 \\
\hline B26 & Emaciation wound & 103.3 & 911 & 829 & -9 \\
\hline $\mathrm{B} 27$ & Gas Gangrene & 87 & 845 & 853.5 & 1 \\
\hline B28 & Ascariasis, weakness & 101 & 614. & 625.3 & 1.8 \\
\hline B29 & Fracture & 119.8 & 563 & 578.8 & 1.9 \\
\hline B30 & $\begin{array}{c}\text { Capillariasis, Coccidiosis, } \\
\text { Gastroenteritis }\end{array}$ & 111.7 & 567.4 & 705.3 & 24.3 \\
\hline B31 & Sinusitis & 104.1 & 498.4 & 533.8 & 7.1 \\
\hline B32 & Ascariasis, Nervousness & 131.4 & 619 & 745.3 & 20.4 \\
\hline B33 & $\begin{array}{c}\text { Nervousness, oil taint, } \\
\text { poisoning }\end{array}$ & 131,9 & 713 & 726.8 & 1.9 \\
\hline B34 & $\begin{array}{c}\text { Capiliariasis,Ectoparaitism } \\
\text { wound, luxation }\end{array}$ & 104.3 & 565 & 574 & 1.6 \\
\hline B35 & Emaciation, weakness & 112.1 & 831 & 857.6 & 3.2 \\
\hline B36 & $\begin{array}{l}\text { Coccidiosis, Gastroenteritis. } \\
\text { wound, Dehydration }\end{array}$ & 105.8 & 568.8 & 603.5 & 6.1 \\
\hline $\mathrm{B} 37$ & Dehydration & 106 & 673.2 & 694.7 & 3.2 \\
\hline B38 & Rhinitis sinusitis & 94 & 601.5 & 638.2 & 6.1 \\
\hline B39 & Ascariasis, Coccidiosis & 115.7 & 550 & 644.6 & 17.2 \\
\hline B40 & Trichomoniasis, wound & 102 & 669 & 801.5 & 19.8 \\
\hline B41 & Emaciation & 103.3 & 731.8 & 688.6 & -5.9 \\
\hline B42 & Ectoparasitism, Electrocution & 105.5 & 767.5 & 597 & 22.2 \\
\hline B43 & Weakness, Luxation & 124.7 & 694 & 884.6 & 27.5 \\
\hline B44 & Coccidiosis, Emaciation & 117.6 & 790.4 & 939 & 18.8 \\
\hline
\end{tabular}




\begin{tabular}{lccccc}
\hline B45 & Ascariasis. wound, amputation & 109.7 & 568 & 647 & 13.9 \\
\hline B46 & Weakness, blindness & 124.5 & 695.8 & 865.6 & 21.5 \\
\hline B47 & Wound, Weakness & 100.6 & 568 & 647 & 13.9 \\
\hline B48 & Dehydration & 118.1 & 695.8 & 865.6 & 24,4 \\
\hline B49 & Ascariasis & 128 & 598.5 & 666.7 & 11.4 \\
\hline B50 & Capillariasis, weakness & 102.8 & 620 & 823.4 & 32.8 \\
\hline AVERAGE & & $\mathbf{1 1 2 . 9}$ & $\mathbf{6 4 2}$ & $\mathbf{9 4 2 . 9}$ & $\mathbf{1 6 . 3}$ \\
\hline
\end{tabular}

Table 2: Categorization of Captive Common Buzzards into Disease Type, Average Food Consumed Daily and Average Weight Gain.

\begin{tabular}{|c|c|c|}
\hline BWNID & $\begin{array}{c}\text { Av. Qty. of Food Consumed Daily } \\
\text { (g) }\end{array}$ & Average Weight Gain (\%) \\
\hline B3 & 113.4 & 32.2 \\
\hline B11 & 130.2 & 19.2 \\
\hline B15 & 127.6 & 20.6 \\
\hline B18 & 111.7 & 21.1 \\
\hline B19 & 118.3 & 17.2 \\
\hline B29 & 119.8 & 1.9 \\
\hline B33 & 131.9 & -1.9 \\
\hline B35 & 112.1 & 3.2 \\
\hline B37 & 106 & 3.2 \\
\hline B41 & 103.3 & -5.9 \\
\hline B42 & 105.5 & 22.2 \\
\hline B43 & 124.7 & 27.5 \\
\hline B46 & 124.5 & 21.5 \\
\hline B48 & 102.8 & 32.8 \\
\hline MEAN & 116.6 & 12.2 \\
\hline \multicolumn{3}{|l|}{ BWID } \\
\hline B2 & 96 & 14.2 \\
\hline B8 & 120.5 & 37.2 \\
\hline B12 & 125.1 & 10 \\
\hline B14 & 104.2 & 2.8 \\
\hline B20 & 110.1 & 21.2 \\
\hline B22 & 119.1 & 45 \\
\hline B23 & 1273.5 & 27.7 \\
\hline B24 & 121.6 & 24.4 \\
\hline B25 & 123.3 & 31 \\
\hline B27 & 87 & 1 \\
\hline B30 & 111.7 & 24.3 \\
\hline B31 & 104.1 & 7.1 \\
\hline B38 & 94 & 6.1 \\
\hline B39 & 115.7 & 17.2 \\
\hline B40 & 102 & 19.8 \\
\hline B49 & 128 & 11.4 \\
\hline MEAN & 111.9 & 18.8 \\
\hline \multicolumn{3}{|c|}{ BWNAID } \\
\hline $\mathrm{B} 1$ & 97.9 & 26 \\
\hline B4 & 106.4 & 20.7 \\
\hline B5 & 118.4 & 24.9 \\
\hline B6 & 101.5 & 19.4 \\
\hline B7 & 107.8 & 30.7 \\
\hline B9 & 110.6 & 31.3 \\
\hline B10 & 125 & 22.7 \\
\hline
\end{tabular}




\begin{tabular}{lll}
\hline B13 & 114.2 & 5.1 \\
\hline B16 & 111.7 & 16.3 \\
\hline B17 & 122.3 & 34.1 \\
\hline B21 & 113.1 & 19.8 \\
\hline B26 & 103.3 & -9 \\
\hline B28 & 101 & 1.8 \\
\hline B32 & 131.4 & 20.4 \\
\hline B34 & 104.8 & 1.6 \\
\hline B36 & 105.8 & 6.1 \\
\hline B44 & 117.6 & 18.8 \\
\hline B45 & 109.7 & 13.9 \\
\hline B47 & 100.6 & 13.9 \\
\hline B50 & 102.8 & 32.8 \\
\hline MEAN & 110.3 & 17.6 \\
\hline
\end{tabular}

KEY:

BWNID $=\quad$ Buzzards with non-infectious diseases

BWID $\quad=\quad$ Buzzards with infectious diseases

BWNAID $=$ Buzzards with non-infectious diseases and infectious diseases

Table 3: Disease Type, Average Quantity of Food Consumed Daily

\begin{tabular}{lccc}
\hline & $\begin{array}{c}\text { Birds with non- } \\
\text { infectious diseases }\end{array}$ & $\begin{array}{c}\text { Birds with infectious } \\
\text { diseases }\end{array}$ & $\begin{array}{c}\text { Birds with both } \\
\text { infectious and non- } \\
\text { infectious diseases }\end{array}$ \\
\hline No food & $116.6 \mathrm{~g}$ & 16 & 20 \\
\hline $\begin{array}{l}\text { Average daily } \\
\text { consumption }\end{array}$ & $14.2 \%$ & $111.9 \mathrm{~g}$ & $110.3 \mathrm{~g}$ \\
\hline Average weight gain & & $18.8 \%$ & $17.6 \%$ \\
\hline
\end{tabular}

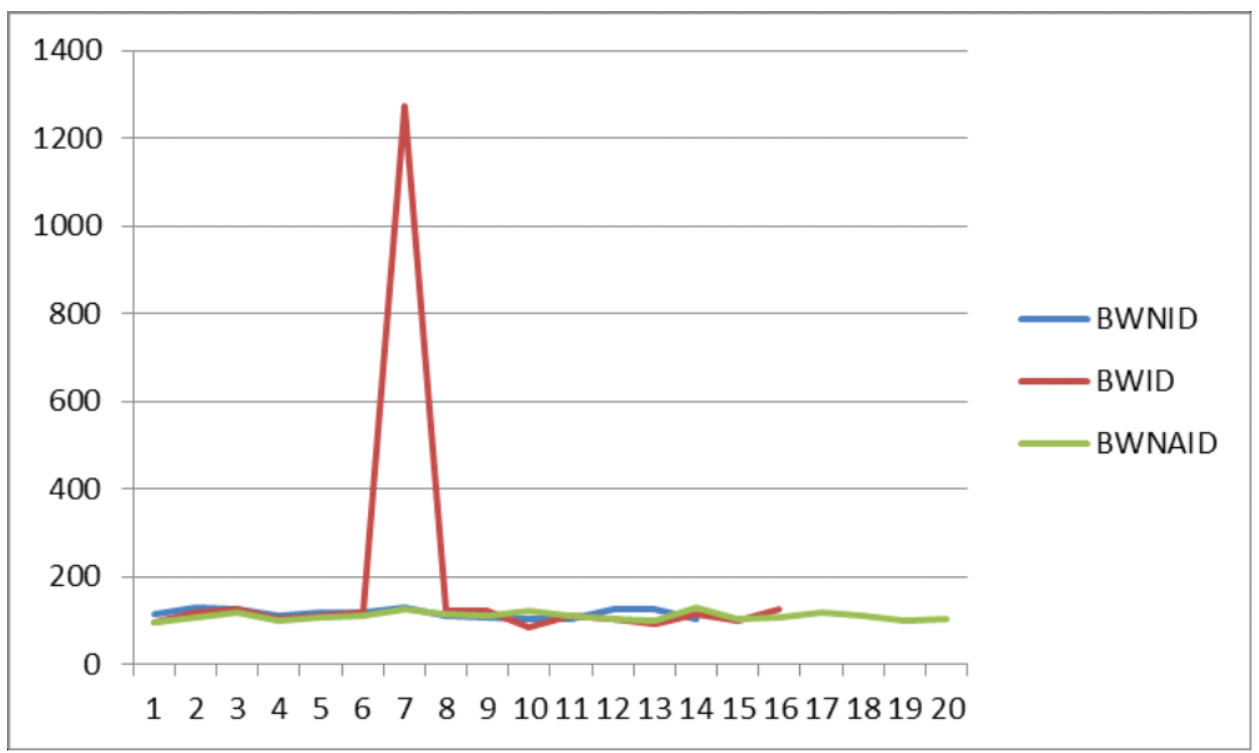

Figure 1: Line plot of average food consumed by different birds with different diseases. 
ANOVA: Single Factor

\begin{tabular}{|c|c|c|c|c|c|c|}
\hline \multicolumn{7}{|l|}{ Summary } \\
\hline Groups & Count & Sum & Average & Variance & & \\
\hline BWNID & 14 & 1631.8 & 116.5571 & 102.9673 & & \\
\hline BWID & 16 & 2935.9 & 183.4938 & 84634.42 & & \\
\hline BWNAID & 19 & 2103.1 & 110.6895 & 82.19544 & & \\
\hline \multicolumn{7}{|l|}{ ANOVA } \\
\hline $\begin{array}{l}\text { Source } \\
\text { Variation }\end{array}$ & $S S$ & $D f$ & $M S$ & $F$ & $P$-value & $F$ crit \\
\hline $\begin{array}{l}\text { Between } \\
\text { Groups }\end{array}$ & 53553.73 & 2 & 26776.87 & 0.968091 & 0.38741 & 3.199582 \\
\hline $\begin{array}{l}\text { Within } \\
\text { Groups }\end{array}$ & 1272334 & 46 & 27659.44 & & & \\
\hline Total & 1325888 & 48 & & & & \\
\hline
\end{tabular}

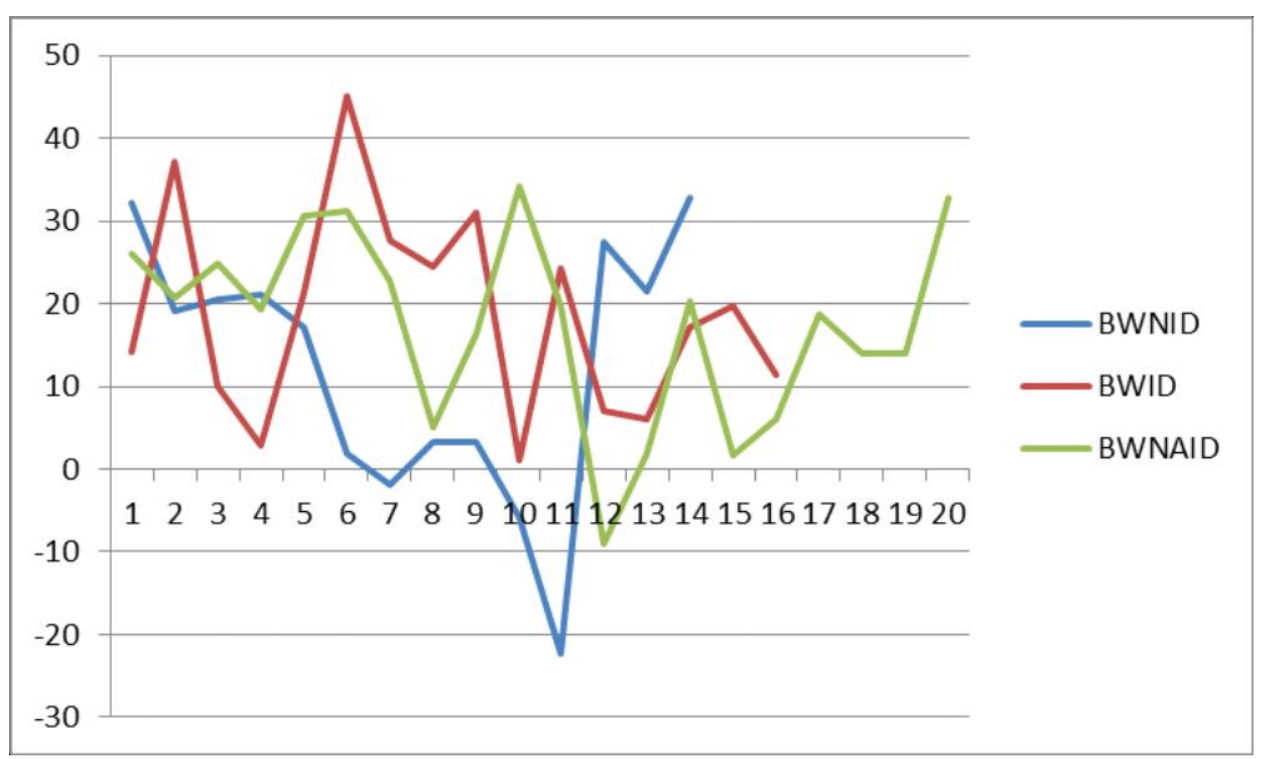

Figure 2: Line Plot of Average Weight Gain by different Birds with different Diseases

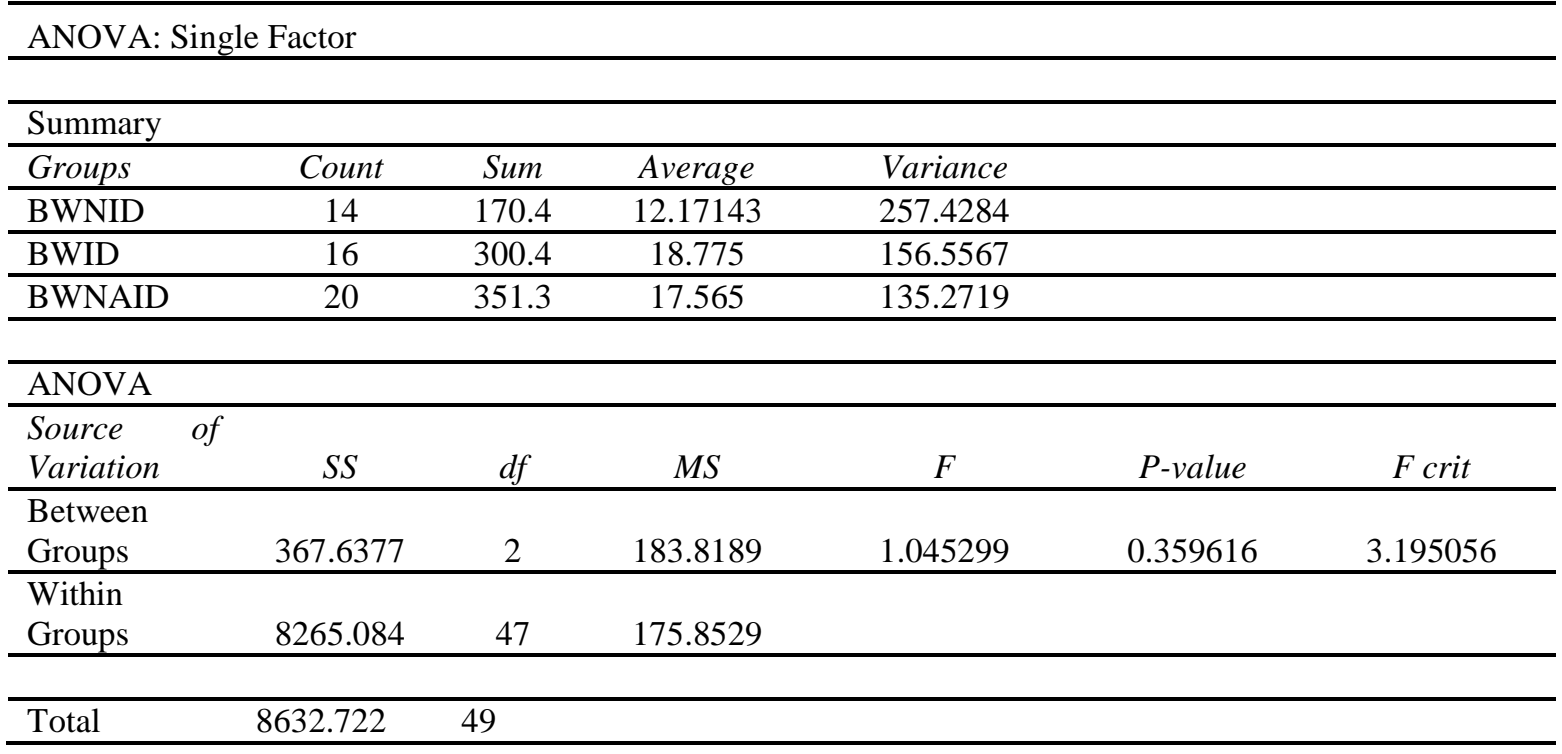

There were no significant differences in average weight gain for the birds with the three categories of diseases. 


\section{DISCUSSION}

Results revealed that buzzards with non-infectious diseases, infectious diseases and those with both infectious and non - infectious diseases, on the average consumed $116.6 \mathrm{~g}, 111.9 \mathrm{~g}$ and $110.3 \mathrm{~g}$ of food daily respectively. The group with noninfectious, infectious and those with both noninfectious and infectious diseases had $12.2 \%, 18.8 \%$ and $17.6 \%$ weight gain respectively.

Buzzards with non-infectious diseases consumed the most quantity of food (111.6g) while those with infectious diseases had the highest weight gain $(18.8 \%)$. This implies that non-infectious disease conditions did not affect food consumption as much as the infectious diseases. On the other hand, birds with infectious diseases gained weight the most because the birds were treated as the research progressed and recovered birds are likely to have improved appetite and food conversion efficiency. It also means that food consumption does not have a direct correlation with food conversion efficiency and weight gain (Cuthbert et al., 2006).

There was no significant difference in the average daily food consumption among the 3 groups of birds studied.

Despite the different disease conditions, most of the buzzards $(98 \%)$ gained weight which might have been limited by the presence of these conditions.

The duration of disease, severity of disease, management of disease conditions, environmental factors and specie and experimental animal type could be possible reasons for the observed results.

\section{CONCLUSION}

Documented relationships exist between disease, food consumption and weight gain. This study showed no significant difference between food consumption in disease conditions and weight gain in disease conditionsin common buzzards. Further studies could be done to investigate and compare the effect of other factors like experimental animal type and weather.

\section{REFERENCES}

Brown, L.H. and Amadon, D. (1968): Eagles, Hawks and Falcons of the world. Country life books, Middlesex.

Cerna, Z. and Louckova, M. (1977): Microtus arvalis, the intermediate host of a coccidian from the Kestrel (Falcotinunculus), Vestnik Coskoslovenske Spolecnosti Zoologicke, 41: 1-4.

Cooper, J.E. (1985a): Diagnostic techniques in birds. The veterinary manual, 25: 236-244.

Cooper, J.E. (1985b): Veterinary aspects of captive birds of prey. 2nd edition steadfast press.

Cuthbert, R.; Green, R.E.; Ranade, S.; Saravanan, S.; Pain, D.J.; Prakash, V. and Cunningham, A.A. (2006): Rapid population declines of Egyptian Vulture (Neophronpercnopterus) and Red-headed Vulture (Sarcogypscalvus) in India. Anim. Conserv. 9: 349-354.

Elghandour, M.M.Y.; Vazquez-Chagoya, J.C.; Kholif, A.E.; Salem, A.Z.M.; MejiaHernandez, P. and Kholif, A.M. (2013): Relationship between nutrition and animal diseases. In; Feed Nutrients and Animal Health. LAMBERT Academic Publishing. Pp.3-36.

Freeman, B.M. (1976): Stress and the domestic fowl. A physiological re-appraisal. World's Poultry Science Journal, 32: 249-256.

Hamilton, W.B. and Zuk, M. (1982): Heritable true fitness and bright birds. A role for parasites. Science, 218: 384-386.

Houde, A.E. and Torio, A.J. (1992): Effects of parasitic infection on male colour pattern and female choice in guppies. Behav. Ecol., 3: 346-351.

Mumcuoglu, Y. and Muller, R. (1974): Parasitische Milben and Wiimerals Todesursacheeines Uhus Bubobubo. Der Ornithologische Beobachter, 7: 289-292.

Tranier, D.O.; Folz, S.D. and Samuel, W.M. (1968): Capilariasis in Gyrafalcon. Condor, 70: 276277.

Von Faber, H. (1964): Sress and general adaptation syndrome in poultry. World's Poultry Science Journal, 20: 175-182. 